\title{
Mithramycin Inhibits SP1 Binding and Selectively Inhibits Transcriptional Activity of the Dihydrofolate Reductase Gene In Vitro and In Vivo
}

\author{
Scott W. Blume," Richard C. Snyder," Ratna Ray," Shelia Thomas, ${ }^{\star}$ Charles A. Koller, ${ }^{\star}$ and Donald M. Miller \\ *Departments of Internal Medicine, Biochemistry, and Comprehensive Cancer Center, University of Alabama at Birmingham \\ and Birmingham Veterans Administration Medical Center, Birmingham, Alabama 35294; \\ and ${ }^{\ddagger}$ Leukemia Branch, M. D. Anderson Hospital, Houston, Texas 77030
}

\begin{abstract}
The promoter of the human dihydrofolate reductase (DHFR) gene contains two consensus binding sites for the DNA binding protein Sp1. DNAse protection and gel mobility shift assays demonstrate binding of recombinant Sp1 to both decanucleotide Sp1 binding sequences which are located 49 and 14 base pairs upstream of the transcription start site. The more distal of the two binding sites exhibits a somewhat higher affinity for Sp1. The G-C specific DNA binding drug, mithramycin, binds to both consensus sequences and prevents subsequent Sp1 binding. Promoter-dependent in vitro transcription of a DHFR template is selectively inhibited by mithramycin when compared to the human $\mathrm{H} 2 \mathrm{~b}$ histone gene. A similar effect is also noted in vivo. Mithramycin treatment of MCF-7 human breast carcinoma cells containing an amplified DHFR gene induces selective inhibition of DHFR transcription initiation, resulting in a decline in DHFR mRNA level and enzyme activity. This selective inhibition of DHFR expression suggests that it is possible to modulate the overexpression of the DHFR gene in methotrexate resistant cells. (J. Clin. Invest. 1991. 88:1613-1621.) Key words: DNA binding drug • methotrexate resistance $\bullet$ gene amplification
\end{abstract}

\section{Introduction}

Dihydrofolate reductase (DHFR) 1 is the product of a "housekeeping" gene, which is transcribed constitutively (1), although its expression is modulated by a number of physiologic and environmental factors (2). DHFR gene amplification and associated overexpression is an important mode of in vitro and in vivo methotrexate resistance (3). The human DHFR gene promoter contains two "G/C box" sequences (4), consensus decanucleotide binding sites for the transcriptional regulatory factor Sp1 (5). Mutagenesis studies of the hamster DHFR promoter demonstrate that the $\mathrm{Spl}$ binding sequences are necessary for transcriptional activity (6). In vitro transcription studies have confirmed the necessity of $\mathrm{Sp} 1$ for DHFR promoter activity (7).

Mithramycin (Plicamycin) is a G-C specific DNA binding drug $(8,9)$ which selectively inhibits transcription of genes,

Address correspondence to Donald M. Miller, M. D., Department of Internal Medicine, Division of Hematology/Oncology, University of Alabama, 1918 University Blvd., BHSB 288, Birmingham, AL 35294.

Received for publication 25 January 1990 and in revised form 11 July 1991.

1. Abbreviation used in this paper: DHFR, dihydrofolate reductase.

The Journal of Clinical Investigation, Inc.

Volume 88, November 1991, 1613-1621 such as the human c- $m y c$ gene, which have G-C rich promoter sequences $(10,11)$. Mithramycin induces myeloid differentiation of leukemic blasts, both in vivo (in leukemic cells of certain patients with blast phase chronic granulocytic leukemia) and in vitro (12). This differentiation is accompanied by a dramatic decrease in the level of expression of the c-myc and c-abl protooncogenes (13), both of which have G-C rich promoters. Mithramycin prevents the binding of $\mathrm{Sp} 1$ and other proteins by the c-myc P1 and P2 promoters (14). It also blocks Sp1 binding to its consensus binding sites in the SV40 early promoter, preventing promoter activity of this sequence (15).

The present work was undertaken to determine whether mithramycin binding to the G-C rich regulatory sequences of the DHFR promoter prevents Spl binding to the $5^{\prime}$ flanking region of this gene, resulting in inhibition of its expression in cells with DHFR gene amplification. In vitro experiments indicate that both mithramycin and the transcriptional regulatory factor Spl bind specifically to the two G/C box sequences in the human DHFR promoter. Mithramycin binding prevents subsequent Sp1 binding to these sequences resulting in inhibition of promoter-dependent in vitro transcription. Mithramycin treatment of methotrexate resistant human breast carcinoma cells in culture induces a decrease in DHFR transcription resulting in a fall in DHFR mRNA levels and DHFR enzyme activity. These experiments indicate that $\mathrm{Sp} 1$ binding is necessary for DHFR transcription initiation and that interference with Sp1 binding to the DHFR promoter results in selective inhibition of DHFR transcription.

\section{Methods}

Preparation of the labelled DHFR promoter fragment. The 367-bp AvalI restriction fragment containing the DHFR transcription start site and the sequence immediately upstream was isolated from the 1.8-kb EcoR1 human DHFR clone (pDHFR1.8) (16). This DHFR promoter fragment sequence was subcloned into the SmaI site in vector pGEM3Z to create pDHFR.37. The 186-bp Not I-EcoR1 digestion product of the AvalI subclone was $3^{\prime}{ }^{32} \mathrm{P}$ end labelled on the DHFR coding strand for use in DNAse protection and gel mobility shift assays. A 118-bp human $\mathrm{H} 2 \mathrm{~b}$ promoter fragment was used as a control (17). This fragment contains no G-C rich protein binding sites and has full promoter activity.

Protein and drug binding assays. The recombinant Spl polypeptide was prepared from pSp1-516C (a gift of R. Tjian, Department of Biochemistry, University of California, Berkeley, CA) as described (18) after expression in BL-21 Escherichia coli. For DNAse 1 protection assays, varying concentrations of the $\mathrm{Sp} 1$ preparation were allowed to equilibrate with $40-100,000 \mathrm{cpm}$ of the 186-bp labelled promoter fragment in the presence of nonspecific competitor DNA (poly d[1-C], 100 $\mu \mathrm{g} / \mathrm{ml}$ ) for $30 \mathrm{~min}$ on ice. Other reaction conditions were: Tris-Cl $\mathrm{pH}$ $8.0,25 \mathrm{mM} ; \mathrm{MgCl}_{2}, 6.5 \mathrm{mM}$; EDTA, $0.5 \mathrm{mM}$; DTT, $0.5 \mathrm{mM}$; KCl, 50 $\mathrm{mM} ; \mathrm{ZnCl}_{2}, 0.5 \mathrm{mM}$; and glycerol, $10 \%$. After the incubation, DNAse I (Boehringer-Mannheim Biochemicals, Indianapolis, IN), $20 \mathrm{U} / \mathrm{ml}$ in $10 \mathrm{mM} \mathrm{MgCl}_{2}, 5 \mathrm{mM} \mathrm{CaCl}_{2}$, was added and limited digestion allowed 
to proceed for $30 \mathrm{~s}$ on ice. Samples were then analyzed on an $8 \mathrm{M}$ urea, $8 \%$ polyacrylamide sequencing gel.

For drug binding experiments, mithramycin (Sigma Chemical Co., St. Louis, MO) was allowed to equilibrate with the labelled DNA fragment in the presence of $3 \mathrm{mM} \mathrm{MgCl}{ }_{2}$ at $37^{\circ}$ for 30 min before digestion with 5-7.5 U/ml DNAse 1 . For gel mobility shift assays, Sp1 binding reactions were carried out as above; Ficoll dye was added, and samples were analyzed on a nondenaturing $5 \%$ polyacrylamide gel. For samples in which DNA was exposed to both mithramycin and Sp1, drug binding conditions were achieved first, after which buffer, competitor DNA, and Spl were added and samples incubated under the appropriate conditions for protein binding.

In vitro promoter-dependent transcription. The 1.8-kb EcoR1 human DHFR fragment or its appropriate restriction fragment was used as a template for in vitro transcription assays. The 118-bp H2b promoter fragment was used as a control. HeLa whole cell extract was prepared according to Manley et al. (19). Template (0.5-1.0 pmol) was first incubated in the presence or absence of mithramycin and $3 \mathrm{mM}$ $\mathrm{MgCl}_{2}$ at $37^{\circ} \mathrm{C}$ for $30 \mathrm{~min}$. The standard $20-\mu 1$ transcription reaction contained $12-\mu l$ whole cell extract, template, $0.5 \mathrm{mM}$ of each ATP, CTP, and GTP, $0.05 \mathrm{mM}$ UTP, $2 \mathrm{mM}$ creatine phosphate, and $4 \mu \mathrm{Ci}$ [a- ${ }^{32}$ P]UTP ( $400 \mathrm{Ci} / \mathrm{mmol}$; Amersham Corp., Arlington Heights, IL). Transcription reactions were allowed to proceed at $30^{\circ} \mathrm{C}$ for $90 \mathrm{~min}$, then were terminated by the addition of $200 \mu \mathrm{l}$ of a solution of $8 \mathrm{M}$ urea, $0.5 \%$ SDS, and $10 \mathrm{mM}$ EDTA. After extraction with phenol/chloroform, $120 \mu \mathrm{l}$ of a solution of $7 \mathrm{M}$ urea, $0.35 \mathrm{M} \mathrm{NaCl}, 10 \mathrm{mM}$ Tris- $\mathrm{HCl}$ ( $\mathrm{pH} 7.9), 10 \mathrm{mM}$ EDTA, and $0.5 \%$ SDS was added along with $20 \mu \mathrm{g}$ carrier tRNA. Samples were again extracted with phenol/chloroform, precipitated with ethanol, and resuspended in $240 \mu \mathrm{l}$ of $0.2 \%$ SDS, $0.3 \mathrm{M}$ sodium acetate ( $\mathrm{pH}$ 5.2), ethanol precipitated, and analyzed on an $8 \mathrm{M}$ urea, $5 \%$ polyacrylamide sequencing gel. The HaeIII restriction fragments of PX174 (Bethesda Research Laboratories, Gaithersburg, MD) and the BamH1/Ssp1 restriction fragments of the 1.8-kb EcoR1 DHFR clone were labelled and used as molecular weight markers.

Inhibition of DHFR transcription in vivo. A methotrexate-resistant derivative of the MCF-7 (20) human breast carcinoma cell line, was a generous gift of K. Cowan, Clinical Pharmacology Branch, National Cancer Institute, Bethesda, MD. For nuclear runon transcription experiments, cells were plated at low density $\left(2.25 \times 10^{6} / 75 \mathrm{~cm}^{2}\right.$-flask $)$ and allowed overnight incubation for adherence. Media was changed and mithramycin (Miles Laboratories, Inc., Elkhart, IN) added at the appropriate concentration for the desired duration of treatment. After drug exposure, cells were collected by centrifugation, resuspended in $400 \mu l$ lysis buffer (10 mM Tris-Hcl pH 7.4, $10 \mathrm{mM} \mathrm{NaCl}, 3 \mathrm{mM}$ $\mathrm{MgCl}_{2}$, and $0.5 \% \mathrm{NP}-40$ ), and incubated on ice for $5 \mathrm{~min}$. Nuclei were collected by low speed centrifugation at $4^{\circ} \mathrm{C}$. Each pellet was then resuspended in $32 \mu \mathrm{l}$ of transcription buffer $\left(240 \mathrm{mM} \mathrm{KCl}, 8 \mathrm{mM} \mathrm{MgCl}_{2}, 64\right.$ $\mathrm{mM}$ Tris- $\mathrm{HCl}$ pH 7.9, $8 \mathrm{mM}$ DTT, 22\% glycerol). The following were added: ATP, CTP, and GTP, $2 \mu l$ each of $25 \mathrm{mM}$ stocks; creatine phosphate, $1 \mu \mathrm{l}$ of $200 \mathrm{mM}$ stock; creatine phosphokinase, $1.2 \mu \mathrm{l}$ of 3 $\mathrm{mg} / \mathrm{ml} \mathrm{stock}$; and $4 \mu \mathrm{l}(40 \mu \mathrm{Ci})\left[\mathrm{a}^{32} \mathrm{P}\right] \mathrm{UTP}$. Runon transcription was allowed to proceed at $30^{\circ} \mathrm{C}$ for $30 \mathrm{~min}$.

Reactions were terminated by the addition of $0.5 \mathrm{ml}$ buffer A ( 10 $\mathrm{mM}$ Tris- $\mathrm{HCl} \mathrm{pH} \mathrm{7.4,} 1 \mathrm{mM}$ EDTA, 0.3\% SDS) and $20 \mu \mathrm{g}$ tRNA, after which $0.5 \mathrm{ml}$ buffer B (100 mM sodium acetate ph 5.2, $20 \mathrm{mM}$ EDTA) was added. The reaction mixtures were extracted with phenol/chloroform and extracted with $0.7 \mathrm{ml}$ buffer $\mathrm{C}(100 \mathrm{mM}$ sodium acetate $\mathrm{pH}$ 5.2, $20 \mathrm{mM}$ EDTA, 0.4\% SDS). After precipitation with ethanol the pellets were resuspended in $150 \mu \mathrm{l}$ Tris-EDTA buffer, brought to $5 \mathrm{mM}$ $\mathrm{MgCl}_{2}, 0.1 \mathrm{mM} \mathrm{CaCl}_{2}, 1 \mathrm{mM}$ DTT, and digested with $1.5 \mathrm{U}$ RNAsefree DNAse 1 at $37^{\circ} \mathrm{C}$ for $20 \mathrm{~min}$. After hybridization, filters were washed four times with $2 \times$ SSC, $0.1 \%$ SDS, air dried, and loaded for autoradiography.

For DHFR enzyme activity assays, $1.1 \times 10^{7}$ cells were plated in $175-\mathrm{cm}^{2}$ flask and allowed $\sim 30 \mathrm{~h}$ for adherence and initiation of growth. The drugs readded every $48 \mathrm{~h}$, as indicated. Cells were harvested using trypsin/EDTA, washed three times in saline, and frozen at $-70^{\circ} \mathrm{C}$. Cell pellets were resuspended in $200 \mu \mathrm{l}$ buffer I $(50 \mathrm{mM}$ Tris$\mathrm{HCl}$, pH 7.4; $100 \mathrm{mM} \mathrm{KCl} ; 10 \%$ glycerol; and $10 \mathrm{mM}$ 2-mercaptoethanol) and sonicated on ice. After centrifugation, the supernatants were assayed for DHFR activity in $100 \mathrm{mM}$ Tris- $\mathrm{HCl} ; \mathrm{pH} 8.0 ; 150 \mathrm{mM} \mathrm{KCl}$; $0.1 \mathrm{mM}$ NADPH; $0.05 \mathrm{mM}$ dihydrofolate; and $0.5 \mathrm{mM}$ 2-mercaptoethanol. The rate of decrease in absorbance at $340 \mathrm{~nm}$ was compared to a standard curve obtained with purified DHFR (Sigma).

\section{Results}

Structure of the human DHFR promoter. Figure 1 illustrates the primary structure of the human DHFR gene promoter. The 1.8-kb EcoR 1 fragment which contains the 5 ' end of the human DHFR gene (16) is shown in panel $A$ (pDHFR1.8). The first
A

B

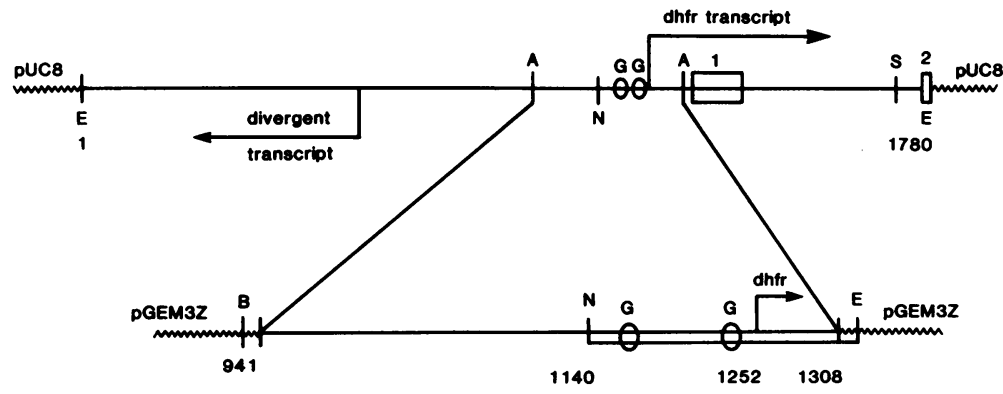

C

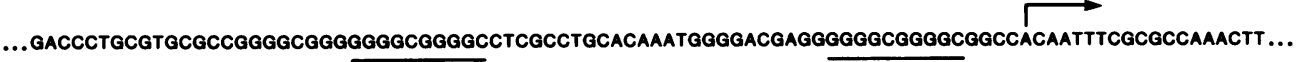

* 1252

Figure 1. The human DHFR promoter contains two $\mathrm{G} / \mathrm{C}$ box sequence elements. $(A)$ Diagram of the 1.8-kb EcoR1 fragment containing the $5^{\prime}$ end of the human DHFR gene. The positions of DHFR exon 1 and the 5 ' portion of exon 2 are indicated by rectangles. The DHFR transcription start site, as well as that for a divergent transcript, are shown by arrows. The two $\mathrm{G} / \mathrm{C}$ box sequence elements near the DHFR transcription start site are represented by ellipses. Numbering proceeds $5^{\prime}$ to $3^{\prime}$ relative to the DHFR coding strand, beginning with the first nucleotide of the recognition sequence of the first EcoR1 site. (B) Diagram of the

367-bp Avall fragment subclone. The double lined segment represents the 186-bp NotI-EcoR1 fragment used for DNAse protection and gel mobility shift assays. Restriction sites: E, EcoR1; A, AvaII; S, SstI; N, NotI; B, BamH1. (C) Sequence of the DHFR coding strand in the region surrounding the $G / C$ box sequences and transcription start site. The transcript is indicated by an arrow. The G/C box decanucleotides are underlined. Nucleotides at which the sequence of the fragment used differs from the published sequence are marked by asterisks: ${ }^{*} \mathrm{~A}$ to $\mathrm{G},{ }^{* *}$ insertion of $\mathrm{G}$. 
exon, first intron, and $5^{\prime}$ end of the second exon, as well as 1.3 $\mathrm{kb}$ of $5^{\prime}$ flanking sequence, are included in this fragment (4). The DHFR transcription start site is located $71 \mathrm{bp}$ upstream of the translation initiation codon. A divergent (non-DHFR) transcription start site is located several hundred bp further upstream. A 367-bp AvalI restriction fragment containing the transcription start site and the sequence immediately upstream was isolated and subcloned (panel $B$; pDHFR.37) to facilitate DNAse protection and gel mobility shift studies of the proximal promoter region. The NotI restriction site, located 112 bp upstream of the transcription start site, was used as a $5^{\prime}$ limit for the proximal promoter region. The two decanucleotide Spl binding sequences ( $5^{\prime}$-GGGGCGGGGC-3') begin 14 and 49 bp upstream of the transcription start site, and each is part of a larger region of G-C rich DNA (panel $C$ ).

Binding of recombinant $S p 1$ to the DHFR promoter sequence. Partially purified recombinant $\mathrm{Sp} 1$ was prepared from the portion of the Sp1 gene, pSp1-516C, cloned by Kadonaga and coworkers (18) after expression of this plasmid in a protease deficient bacterial host. The expressed protein product contains the three zinc fingers responsible for DNA sequencespecific binding, the polypeptide region responsible for the affinity characteristics of Spl binding, as well as the domain responsible for activation of transcription (21).

To characterize binding of the recombinant $\mathrm{Sp} 1$ to the DHFR promoter sequence, DNAse I protection (footprinting) experiments were performed (Fig. 2). The position of the two Sp1 binding sequences and the DHFR transcription start site are indicated by the Maxam-Gilbert G-specific sequence reac-

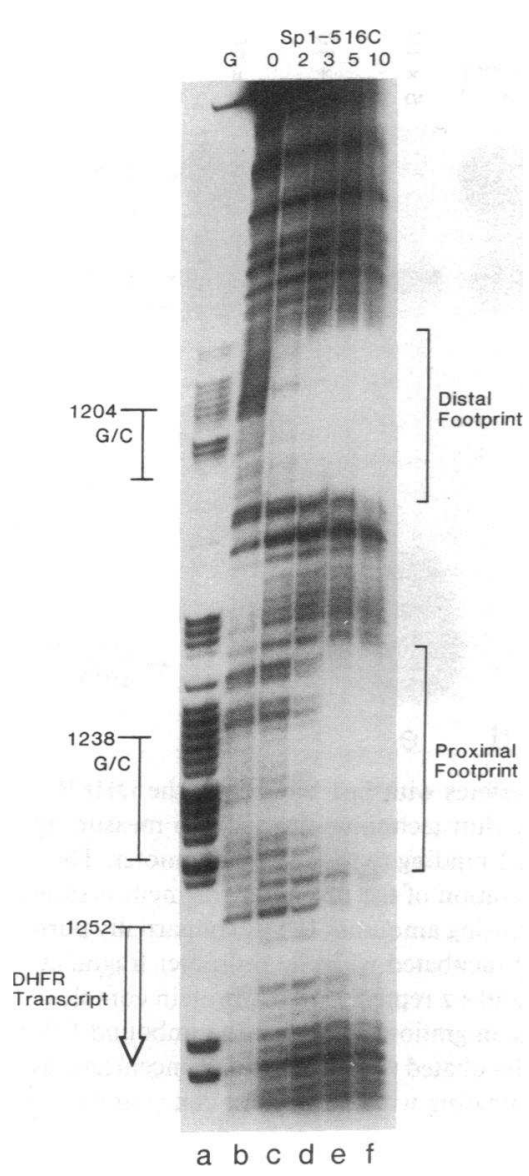

Figure 2. Sp1 binds to the two $\mathrm{G} / \mathrm{C}$ box sequences of the human DHFR promoter.

DNAse 1 protection was used to assay binding of Sp1-516C to the coding strand of the human DHFR promoter. A Maxam-Gilbert G-specific sequence reaction (lane $a$ ) indicates the position of the $\mathrm{G} / \mathrm{C}$ box sequences and the transcription start site. A control (no Spl added) DNAse 1 digestion of the promoter fragment is shown in lane $b$. In lanes $c-f$, increasing concentrations of the Sp1-516C preparation were incubated with the promoter fragment before digestion. The numeral over each lane indicates the $\mu \mathrm{g}$ of total protein of the recombinant $\mathrm{Sp} 1$ preparation added in each $20-\mu$ l total binding reaction. Regions of DNAse protection (footprinting) are bracketed. tion (lane $a$ ). A control sample without added Spl (lane $b$ ) and four samples incubated with increasing concentrations of Sp1 before digestion (lanes $c-f$ ) are shown. Two specific regions of protection coinciding with the two $\mathrm{Sp} 1$ binding site sequences were seen. The position and extent of the two protected sequences indicate that each represents the binding of one molecule of $\mathrm{Spl}$ to one of the $\mathrm{Spl}$ binding site sequence elements. The distal (relative to the DHFR coding sequence) footprint became evident at a lower $\mathrm{Sp} 1$ concentration than that at which the proximal footprint was seen, indicating a somewhat higher affinity of the distal binding site for Spl binding. The sequences surrounding the two Sp1 binding sites or the secondary structure of the DNA in these regions may be important in determining Spl binding affinity since the decanucleotide sequences are identical (21).

Binding of mithramycin to the DHFR promoter sequence. Mithramycin binds to DNA sequences which contain a minimum of two contiguous dG-dC base pairs (9). DNAse I protection was used to compare the sites of mithramycin binding on the human DHFR promoter to those of Sp1 (Fig. 3). A Maxam-Gilbert G-specific sequence reaction (lane $a$ ), control DNAse digestion (lane $b$ ), and DNAse I digested samples pretreated with increasing concentrations of mithramycin before digestion (lanes $c-e$ ) are shown. Two specific areas of mithramycin binding were revealed, each in the region of one of the two Spl binding sites (lanes $d$ and $e$ ). The distal mithramycin footprint was slightly more $5^{\prime}$, and the proximal mithramycin footprint was slightly more $3^{\prime}$, relative to the Sp1 footprints. DNAse hypersensitivity was seen in the nucleotides adjacent to each of the two mithramycin footprints. These may represent drug-induced alterations in DNA conformation which facilitate endonuclease attack. The degree of DNAse protection afforded by mithramycin was relatively comparable at each of the two Spl binding site sequences.

Effect of mithramycin binding on Spl binding to the DHFR promoter. Gel mobility shift assays were used to test whether mithramycin binding interferes with the binding of Sp1 to the human DHFR promoter fragment (Fig. 4). In the control sample (untreated, radiolabelled fragment), a single intense band was seen near the bottom of the gel representing the normal migration of the 186-bp DNA promoter fragment with no protein bound (lane $a$ ). At a low concentration of Sp1 (lane $b$ ), two closely spaced bands (s-x, s-y) which migrate more slowly than the unbound DNA were seen. At a higher Spl concentration (lane $c$ ) a third, more slowly migrating band (s-z) appeared. As the $\mathrm{Sp} 1$ concentration was increased further (lane $d$ ) the most slowly migrating shifted band (s-z) increased in intensity while the shifted doublet (s-x, s-y) faded. At the same time, the unshifted band disappeared as progressively more DNA was bound by $\mathrm{Sp} 1$.

Correlation of these results with those of the DNAse protection experiments, which were carried out under identical binding conditions, suggests that the shifted bands s- $x$ and s-y represent binding of a single Sp1 molecule to one of the Spl binding sequences. The consistent relative intensities of the s-x and s-y bands correlate with the relative affinities of the proximal and distal Sp1 binding sites respectively. At the highest Sp1 concentration, both $\mathrm{Sp} 1$ binding sites were completely protected from DNAse activity, and s-z became the predominant shifted band. It is likely, therefore, that this band represents the complex of two molecules of Spl bound simultaneously to the two Sp1 binding site sequences on the DHFR promoter. 


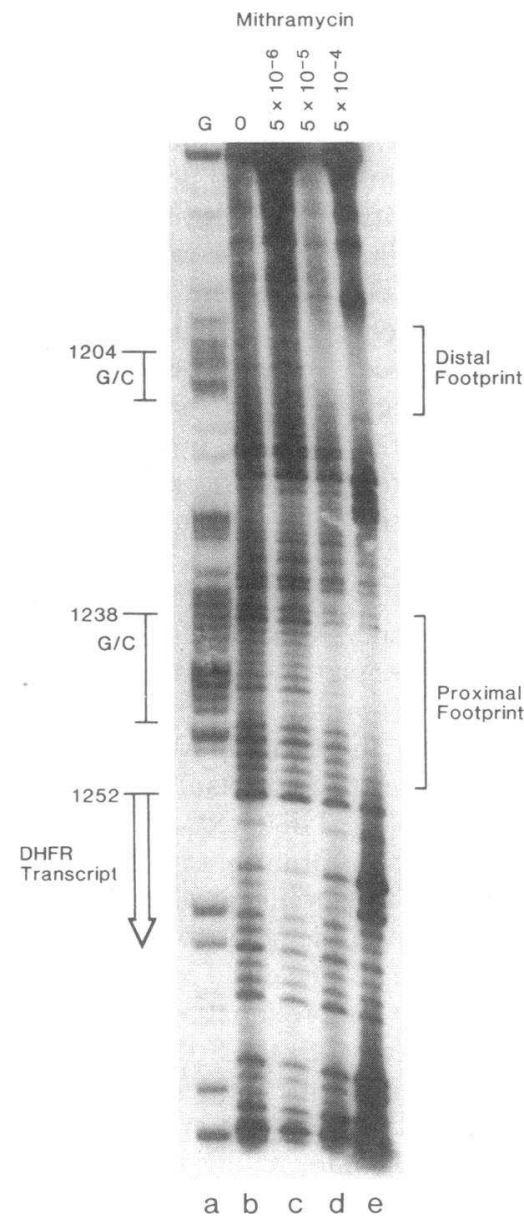

Figure 3. Mithramycin binds to the two G/C box sequences of the human DHFR promoter. DNAse 1 protection was used to assay binding of mithramycin to the coding strand of the human DHFR promoter. A Maxam-Gilbert G-specific sequence reaction (lane $a$ ) indicates the position of the $\mathrm{G} / \mathrm{C}$ box sequences and the transcription start site. A control (no mithramycin added) DNAse 1 digestion of the promoter fragment is shown in lane $b$. In lanes $c-e$, increasing concentrations of mithramycin were incubated with the promoter fragment before digestion. Regions of DNAse protection (footprinting) are bracketed.

To determine the effect of mithramycin on Sp1 binding, the DHFR promoter fragment was also incubated with mithramycin before the $\mathrm{Sp} 1$ binding reaction. Although the same concentration of Spl was used in lanes $e-g$ as in lane $d$, the pattern of shifted bands was altered. Preincubation of the DNA with a high concentration of mithramycin (lane $e$ ) prevented nearly all Sp1 binding; band s-z was absent, the doublet (s-x, $s-y$ ) was greatly decreased in intensity, and the majority of the DNA was unshifted. This mithramycin effect was concentration dependent (lanes $f-g$ ) and corresponds to the footprinting effects of the drug.

Effect of mithramycin on in vitro transcription of the DHFR promoter. To determine the functional consequences of mithramycin binding to the DHFR promoter, we investigated the effect of this agent on promoter-dependent in vitro transcription. When the 1.8-kb EcoR1 DHFR fragment was incubated with ribonucleotides and a HeLa whole cell extract containing RNA polymerase II, the 529-nt DHFR transcript as well as an $\sim 650$-nt divergent transcript generated several hundred bp upstream of DHFR were synthesized (data not shown). The direction of each transcript was confirmed when restriction digests which removed sequence either from the $5^{\prime}$ (Ssp1) or 3' (Sst1) end of the 1.8-kb template appropriately altered the size of the divergent or DHFR transcripts, respectively.

A series of template molecules was prepared in which progressively more 5 ' sequence was removed from the original 1.8 -

kb fragment. Templates with 821 bp, 565 bp, 322 bp, and 112 bp of $5^{\prime}$ flanking sequence (relative to the DHFR transcription start site) were tested, each retaining the ability to be efficiently transcribed to produce the 529-nt DHFR transcript (data not shown). The functional template produced by Not 1 restriction of the 1.8-kb EcoR 1 fragment contains the same upstream promoter sequence (112 bp) as the 186-bp fragment of the AvalI subclone used in DNAse protection and gel mobility studies, although additional 3 ' sequence is used to facilitate detection of the transcript on autoradiography.

In Fig. 5, the effect of mithramycin on in vitro transcription of the Not 1 restricted template is shown. A reaction with no added template DNA (lane $a$ ) showed only nonspecific bands. In the control DHFR transcription reaction (lane $b$ ), the 529-nt DHFR transcript was seen. This band was decreased in intensity by preincubation of the template with a low concentration of mithramycin (lane $c$ ). Synthesis of the DHFR transcript was completely inhibited by the higher mithramycin concentrations (lanes $d-e$ ). This concentration-dependent interference by mithramycin with DHFR promoter function correlates with the binding of the drug to the promoter and its inhibition of $\mathrm{Sp} 1$ binding as measured in DNAse protection and gel mobility shift experiments. Inhibition of $\mathrm{H} 2 \mathrm{~b}$ transcription was significantly less sensitive to mithramycin than DHFR at all concentrations tested. At $1 \times 10^{-5} \mathrm{M}$ mithramycin DHFR transcription was inhibited by $36 \%$ while $\mathrm{H} 2 \mathrm{~b}$ transcription was not significantly inhibited.

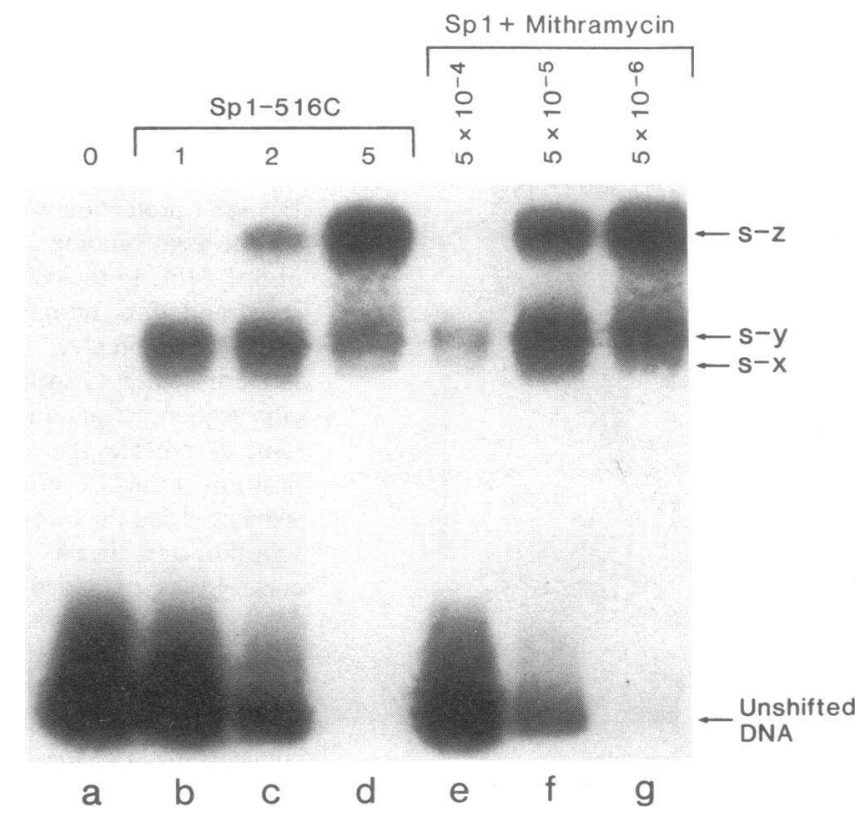

Figure 4. Mithramycin interferes with Sp1 binding to the DHFR promoter. The gel mobility shift technique was used to measure the effect of mithramycin on Spl binding to the DHFR promoter. The control (no Spl added) migration of the promoter fragment is shown in lane $a$. In lanes $b-d$, increasing amounts (1-5 $\mu \mathrm{g})$ of partially purified recombinant $\mathrm{Sp} 1$ were incubated with the promoter fragment. The shifted bands s-x, s-y, and s-z represent DNA-protein complexes with altered electrophoretic migration relative to the unbound DNA. In lanes $e-g$, DNA was preincubated with decreasing concentrations of mithramycin before incubating with the highest concentration of $\mathrm{Sp} 1(5 \mu \mathrm{g})$. 

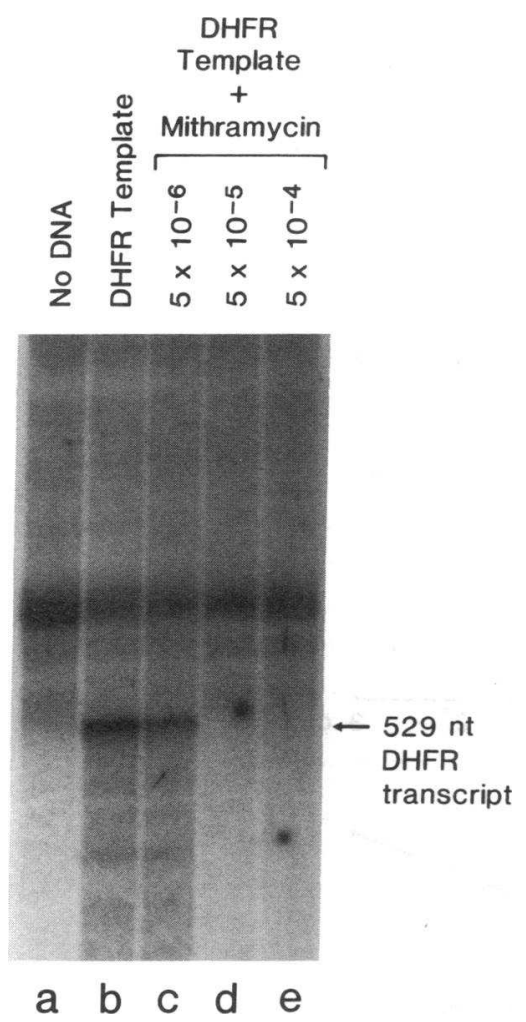

Figure 5. Mithramycin inhibits in vitro promoter-dependent transcription of DHFR. The NotI restricted DHFR template was incubated with an RNA polymerase II containing HeLa whole cell extract in the presence of ribonucleotides and $\left[a-{ }^{32}\right.$ P]UTP to allow for in vitro promoter-dependent synthesis of the DHFR transcript. A transcription reaction with no added template is shown in lane $a$. In lane $b$, the result of the control DHFR transcription reaction is seen. In lanes $c-e$, the DHFR template DNA was preincubated with increasing concentrations of mithramycin before the transcription reaction. The number over each lane indicates the mithramycin concentration in $\mathrm{mmol} / \mathrm{ml}$ of each binding reaction.

Interestingly, mithramycin also inhibited in vitro transcription of the divergent promoter sequence (observed when the 1.8-kb template was used). This transcription start site, like that of DHFR, is preceded by very G-C rich sequences, including one exact $\mathrm{G} / \mathrm{C}$ box decanucleotide. On the other hand, transcription of a human $\mathrm{H} 2 \mathrm{~b}$ template was 10 -fold less sensitive to inhibition by mithramycin in the same system (data not shown).

Effect of mithramycin on intracellular DHFR transcription. To detect the in vivo effect of mithramycin on intracellular DHFR transcriptional activity, runoff transcription of DHFR by nuclei isolated from whole cells exposed to mithramycin was measured (Fig. 6). A methotrexate-resistant derivative of the human breast carcinoma MCF-7 was used for these experiments. This cell line, developed by Cowan and coworkers, is characterized by DHFR gene amplification and overexpression (20). Hybridization of radiolabelled transcript RNA to the 1.8-kb EcoR1 DHFR fragment indicated that DHFR transcription by the cells exposed to higher mithramycin concentrations was almost completely inhibited within $9 \mathrm{~h}$ of the onset of drug exposure (panel $A$ ). A lower concentration of mithramycin caused a slower, but similarly effective, inhibition of DHFR transcription initiation (panel $B$ ). Transcriptional activity detected by a human tubulin probe followed a pattern similar to that of DHFR, as expected since the tubulin promoter contains Spl binding sequence. However, transcriptional activity of the human $\mathrm{H} 2 \mathrm{~b}$ gene was considerably less sensitive to inhibition by mithramycin (data not shown). The total transcriptional activity of nuclei isolated from mithramycintreated cells was identical to that of nuclei from untreated control cells.

The transcriptional inhibition of DHFR by mithramycin is reflected in the concentration of DHFR mRNA in cells that have been exposed to mithramycin. As shown in Fig. 7, treatment of the methotrexate-resistant MCF-7 cells with mithramycin resulted in a significant decrease in the level of DHFR mRNA in both control, and methotrexate treated cells. In addition, mithramycin completely abrogated the increase in DHFR mRNA in response to exposure to methotrexate, although there is no evidence that this increase is transcriptionally mediated.

Effect of mithramycin on the intracellular level of DHFR gene product. To measure the end result of the transcriptional inhibition of DHFR by mithramycin, DHFR enzyme activity was assayed in the homogenate of cells treated by continuous exposure to the drug (Fig. 8). Use of the DHFR gene amplified cells facilitates measurement of the normally low level of activity of the housekeeping enzyme. Panel $A$ illustrates the effect of
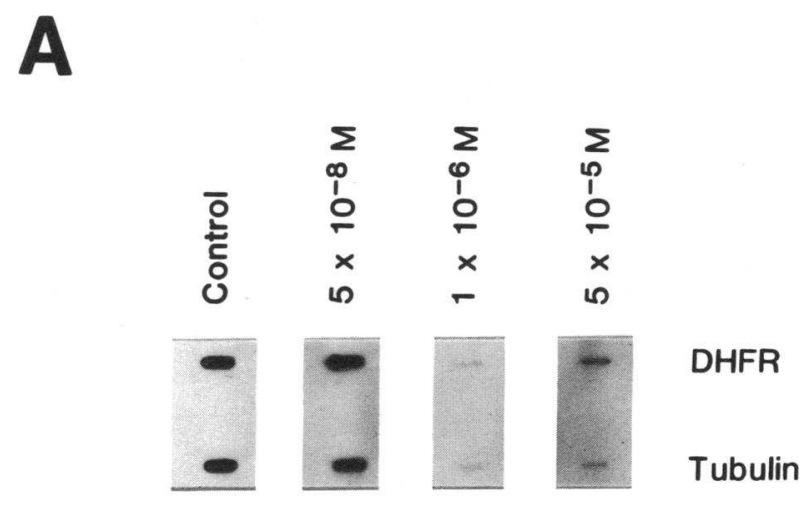

\section{Hours Exposure to Mithramycin}
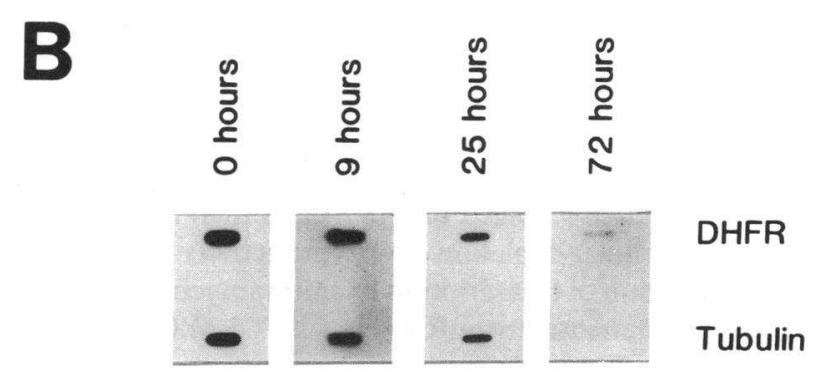

\section{$5 \times 10^{-8} \mathrm{M}$ Mithramycin}

Figure 6. Mithramycin inhibits intracellular transcription initiation of DHFR. The technique of nuclear runoff transcription was used to determine the effect of mithramycin on intracellular DHFR transcriptional activity. DHFR gene amplified cells were treated with mithramycin. Nuclei were isolated and runoff transcription allowed to proceed in the presence of [ $\left.a-{ }^{32} \mathrm{P}\right] U$ TP. Labelled RNA was then allowed to hybridize to the 1.8-kb EcoR 1 human DHFR fragment in order to measure the drug effect on the level of intracellular DHFR transcription. A human tubulin probe was used as a reference. $(A)$ Mithramycin concentration was varied with a 9-h duration of drug exposure. $(B)$ The duration of drug exposure was varied with a constant concentration of mithramycin. 


\section{Methotrexate}

\section{Methotrexate Mithramycin}

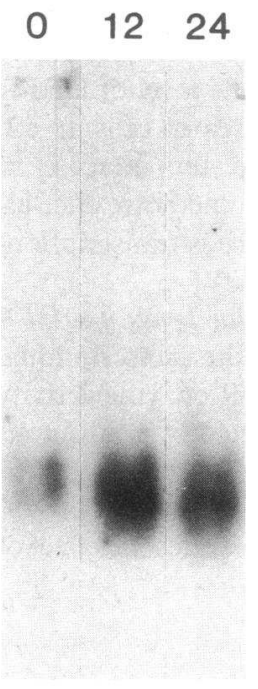

123
1224

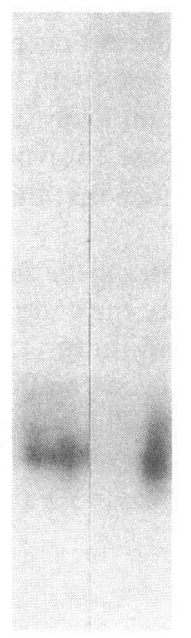

45

\section{Mithramycin}
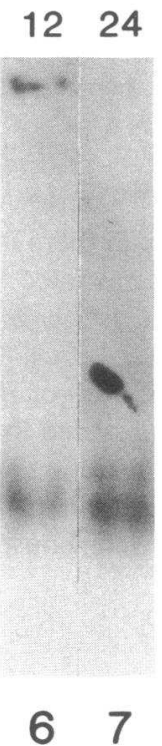

Figure 7. Mithramycin causes a decline in intracellular DHFR mRNA. Northern analysis of RNA isolated from methotrexate resistant MCF-7 cells treated with mithramycin and/or methotrexate was used to determine drug effects on DHFR mRNA levels. Drug concentrations used were: methotrexate, $5 \times 10^{-7} \mathrm{M}$; mithramycin, 5 $\times 10^{-8} \mathrm{M}$. The number over each lane represents the duration of drug exposure in hours.

mithramycin on cellular proliferation. Untreated cells supplemented with fresh medium divided rapidly until they began to approach confluence $\sim 48 \mathrm{~h}$ into the experiment. Mithramycin-treated cells divided normally for $24 \mathrm{~h}$ but reached a plateau at a cell density below confluence. Panel $B$ shows total DHFR enzyme levels assayed for each sample in panel $A$. Stimulation of control cells with fresh serum (arrow at $15 \mathrm{~h}$ ) induced a transcription-mediated increase in DHFR enzyme activity. Mithramycin-treated cells showed a much lower level of serum induction of DHFR. Control cells maintained the elevated DHFR activity as they proliferated. In mithramycin-treated cells, DHFR activity leveled off $(48 \mathrm{~h})$ and then began to decline $(72 \mathrm{~h})$. Cellular depletion of enzyme activity depends not only on inhibition of transcription by mithramycin but also on the decay of pretreatment mRNA $\left(t_{1 / 2}=7.5 \mathrm{~h}\right)(22)$ and enzyme $\left(t_{1 / 2}=\sim 28 \mathrm{~h}\right)(23)$ levels.

In panel $C$ the effect of mithramycin and/or methotrexate treatment is measured in terms of DHFR activity per cell. After $24 \mathrm{~h}$ of exposure to mithramycin or mithramycin plus methotrexate, treated cells had roughly $50 \%$ the DHFR activity of untreated cells. After $4 \mathrm{~d}$ of continuous drug exposure, mithramycin-treated cells contained $\sim 15 \%$ of the DHFR activity per cell of their untreated counterparts. This level of DHFR activity approaches that of the parent MCF-7 cells in which the DHFR gene is not amplified or overexpressed. This decrease in DHFR activity per cell represents a considerable lowering of the parameter responsible for methotrexate resistance in these cells. There was no change in the total protein concentration of the mithramycin treated cells.

\section{Discussion}

Regulation of DHFR gene expression. Although DHFR is constitutively expressed in all cells, a number of physiologic and environmental stimuli influence the rate of transcription of this gene. DHFR expression increases in early $S$ phase of the cell cycle $(1,22,24)$. The addition of fresh serum to cells in

A

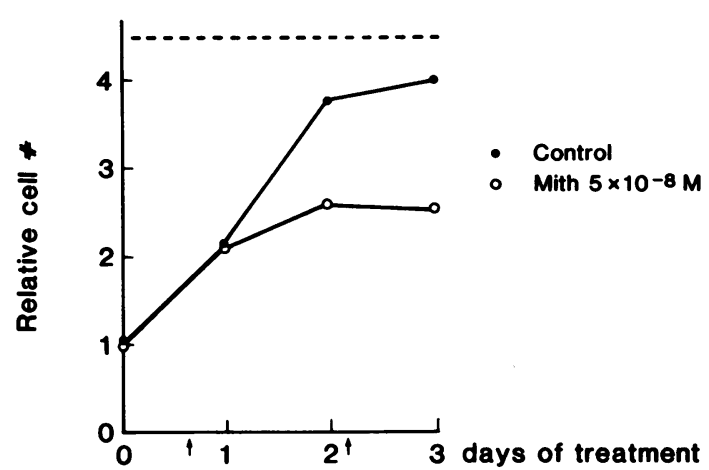

B
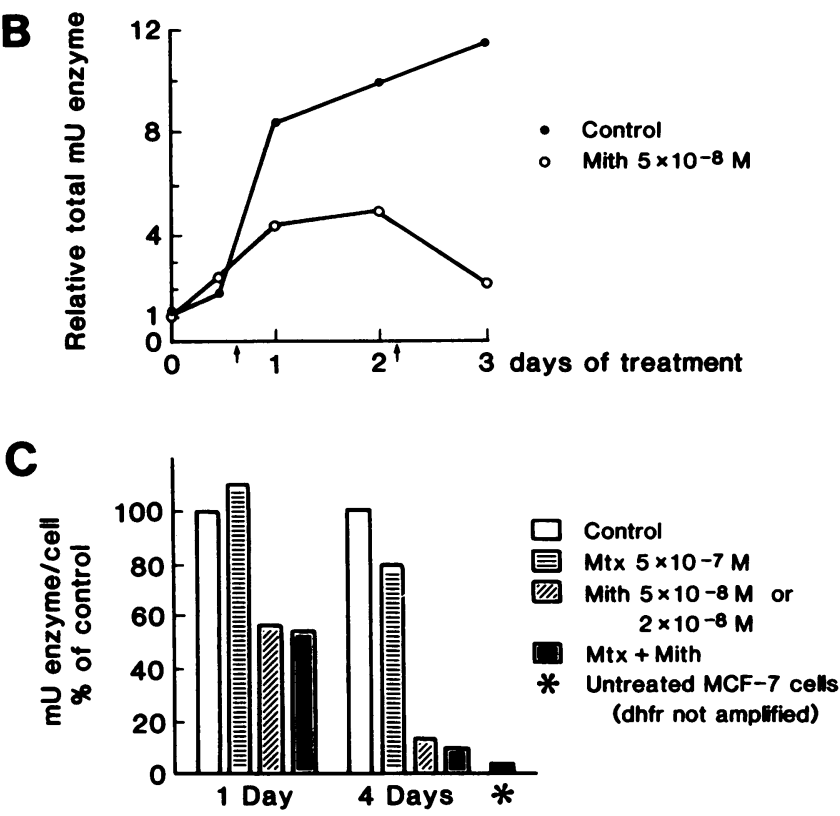

Figure 8. Mithramycin causes a decline in intracellular DHFR enzyme activity. DHFR enzyme activity was assayed spectrophotometrically on the homogenate of cells treated by continuous exposure to mithramycin in order to determine the effect of the drug on intracellular DHFR gene product levels. $(A)$ Effect on cellular proliferation. Cell number is expressed relative to the onset of treatment. The dotted horizontal line approximates cellular confluence. Arrows along the horizontal axis indicate points at which media was changed and drug added. $(B)$ Effect on DHFR enzyme synthesis. The samples from $(A)$ above were lysed and the cell homogenate assayed for DHFR enzyme activity. Results are expressed as total activity per sample, relative to the start of treatment. $(C)$ Cellular depletion of DHFR. DHFR activity per cell after varying treatments is shown. Results are expressed as a percent of untreated cell values. For reference, the relative cellular DHFR activity of non-gene amplified parent MCF-7 cells harvested under growth conditions comparable to 4-d samples is shown in the bar marked with an asterisk. 
culture stimulates DHFR transcription, while cellular confluence is associated with a decrease in expression $(2,25)$. Mouse erythroleukemia cells exhibit a dramatic decrease in DHFR transcription when chemically induced to differentiate (26).

Although the extent of regulatory sequences which control expression of the DHFR gene is unknown, our data indicate that 112 bp $5^{\prime}$ of the transcription start site is sufficient for in vitro transcription. This is consistent with the results obtained by other workers in experiments in which a DHFR minigene limited to the same 112 bp of promoter sequence was functional in transfected DHFR-deficient Chinese hamster ovary cells (16). This promoter segment includes both the distal and proximal Spl binding site sequences, and is located within an open chromatin (nonnucleosomal), CpG hypomethylated region of DNA (7).

A number of genes which bind $\mathrm{Sp} 1$ have now been identified (27-31). From the known Spl binding sites, a consensus decanucleotide sequence has been proposed; within this consensus, the sequence 5'GGGGCGGGGC3' (sometimes referred to as the heptanucleotide 5'GGGGCGG3'), of which each of the human DHFR Spl binding site sequences consist, represents the most preferred, highest affinity $\mathrm{Sp} 1$ binding site (5). Spl binding sites vary in number, relation to the transcription start site, and to each other as well as among heterologous regulatory elements in the different promoters in which they are found. The most proximal Sp1 binding site is frequently positioned 40-60 bp upstream of the transcription start site $(5$, 32-34). Activation of transcription by Sp1 has been demonstrated in vitro and in vivo for several of these genes.

Our data demonstrate that the human DHFR promoter binds two molecules of $\mathrm{Sp} 1$ at the two Spl binding site sequences. Our in vitro data suggest that $\mathrm{Sp} 1$ binding is necessary for DHFR transcription. The distal Spl binding site sequence begins 49 bp upstream of the transcription start site. It is associated 6 bp downstream with the sequence 5 -TGCACAAATGGGG-3', a "CAA element" homologous among the human, mouse, and hamster DHFR genes $(6,33,34)$. The association of a G/C box and a CAA element has been found to precede by $\sim 50$ bp the transcription start sites of these three mammalian DHFR genes. Both $\mathrm{Spl}$ and a Spl binding site have been shown to be essential for DHFR transcription in the mouse (6, 33). Because of its high affinity for Sp1, its position relative to the transcription start site, and its homologous association with the CAA element, the distal Sp1 binding site of human DHFR gene would be expected to be critically involved in transcription initiation of the DHFR gene.

The proximal G/C box of the human DHFR promoter is located only 4 bp upstream of the transcription start site. The decanucleotide sequence comprises a strong Spl binding site, and the DNAse protection assay shows clear binding albeit with lower affinity than the distal $\mathrm{G} / \mathrm{C}$ box. It is conceivable that $\mathrm{Sp} 1$ binding to the proximal binding site could either stimulate, inhibit, or be independent of DHFR transcription.

The positive transcriptional activity of a relatively weak Sp1 binding site in the LDL receptor promoter can be downregulated by the action of an adjacent sterol-dependent response element. When the Spl binding sequence was changed to a high affinity $\mathrm{Sp} 1$ binding sequence by site directed mutagenesis, the promoter became constitutive, unresponsive to the adjacent element (35). A similar significance of the Sp1 affinity of multiple $\mathrm{Sp} 1$ binding sequences can be found in the herpes simplex virus thymidine kinase promoter (29). These variations in multiplicity, spatial arrangement, and affinities of transcription factor binding sites may be responsible for differential patterns of gene expression (36).

Methotrexate resistance and modulation of DHFR gene expression. DHFR gene amplification has been demonstrated in a number of methotrexate-resistant human (37-39) and animal $(25,33,40-43)$ cell lines, and documented clinically in a number of cases of methotrexate resistant neoplasms (44-46). The methotrexate resistant cells used in this work have an $\sim 25$-fold increase in DHFR gene copy number, mRNA, and enzyme activity, but a disproportionately high $(10,000 \times)$ increase in methotrexate resistance (20). The association of a small increase in gene dosage with a large increase in drug resistance is a consistent finding. No other mode of methotrexate resistance has been found for these cells.

Spl binding appears to be critical for DHFR transcription. Because of this, the G-C specific DNA binding drug mithramycin represents an initial candidate for an attempt to selectively inhibit the transcriptional activity of the human DHFR promoter. This molecule binds G-C rich DNA and inhibits DNAdependent RNA synthesis in vitro; in vivo data has shown that mithramycin selectively inhibits expression of genes with G-C rich promoters.

DNAse I footprinting experiments demonstrated that mithramycin binds specifically to the same two G/C box regions of the human DHFR promoter as Sp1. The drug concentrations that result in mithramycin binding to the DHFR promoter are comparable to those used in the original studies on mithramycin binding specificity. In contrast to Sp1, mithramycin shows no difference in binding affinity between the two sites. The specific DNAse enhancements which are seen at the highest mithramycin concentration suggest that mithramycin binding induces a different type or greater degree of conformational alteration on the DNA than Spl binding (23).

The abrogation of the Sp1-induced gel mobility shifts indicates that mithramycin binding prevents subsequent $\mathrm{Sp} 1$ binding to the DHFR promoter in vitro. This suggests that mithramycin interferes with $\mathrm{Spl}$ binding and the formation of the DHFR transcription initiation complex. The concentrations of mithramycin that result in binding of the DHFR promoter and prevention of Spl binding also effectively inhibit promoter-dependent in vitro transcription of DHFR. The selective inhibition of DHFR, as compared to histone $\mathrm{H} 2 \mathrm{~b}$, suggest that inhibition of Spl binding is causally related to inhibition of DHFR transcription.

The nuclear runoff, Northern analysis, and enzyme assay experiments confirm that mithramycin also inhibits DHFR transcription initiation in whole cells and induces a selective decrease in DHFR mRNA and enzyme activity. Drug treatment significantly lessened the increase in DHFR activity in response to serum stimulation. After $72 \mathrm{~h}$ of mithramycin exposure, DHFR transcription was essentially abolished. The rate of decrease in DHFR enzyme activity was consistent with first order decay and the estimated half-life of the enzyme. After $96 \mathrm{~h}$ of mithramycin treatment, DHFR gene amplified cells contained only slightly greater DHFR activity than that present in non-gene amplified cells under comparable growth conditions. Since mithramycin inhibits DHFR transcription and causes the overexpressed enzyme to be depleted, the sensi- 
tivity to methotrexate should be returned to near normal. The lack of the expected mithramycin-methotrexate synergism suggests that expression of other genes, presumably genes important in the control of cellular proliferation, are also being inhibited. In fact, it has recently been shown that mithramycin inhibits protein binding and transcriptional activity of the c$m y c$ gene, as well (14). This gene, which plays an important role in the regulation of cellular proliferation, also has a G-C rich promoter.

With a recognition sequence of three base pairs limiting its specificity, mithramycin undoubtedly affects the expression of multiple genes with G-C rich promoter elements. This allows for the possibility that mithramycin inhibits the expression of one or more genes other than DHFR which may: (a) be lethal to the cell (primary mithramycin toxicity) (47), which would supercede synergism; $(b)$ alter the program for the cell cycle (antiproliferative effect of mithramycin) which could obscure any mithramycin-induced increase in methotrexate sensitivity $(48,49)$; or $(c)$ eliminate a gene product which is necessary for the mechanisms of toxicity of methotrexate $(50,51)$. An agent with greater sequence specificity than mithramycin might not exhibit such effects.

\section{Acknowledgments}

We thank Dr. K. Cowan and Dr. Merrill Goldsmith for helpful discussion of this project as well as the MR100 cells and DHFR probes. We are grateful to Ms. Barbara Wilson for her expert assistance in preparation of this manuscript.

S. W. Blume is a postdoctoral fellow of the American Cancer Society (PRTF-94). This work was supported by grants from the National Institutes of Health (CA 42664 and CA 42337), Leukemia Society of America, and the Veterans Administration Research Program to Donald M. Miller.

\section{References}

1. Farnham, P. J., and R. T. Schimke. 1985. Transcriptional regulation of mouse dihydrofolate reductase in the cell cycle. J. Biol. Chem. 260:7675-7680.

2. Levine, R. M., E. Rubalcaba, M. E. Lippman, and K. H. Cowan. 1985. Effects of estrogen and tamoxifen on the regulation of dihydrofolate reductase gene expression in a human breast cancer cell line. Cancer Res. 45:1644-1650.

3. Schimke, R. T. 1986. Methotrexate resistance and gene amplification. Cancer (Phila.). 57:1912-1917.

4. Chen, M., T. Shimada, A. D. Moulton, A. Cline, R. K. Humphries, J. Maizel, and A. W. Nienhuis. 1984. The functional human dihydrofolate reductase gene. J. Biol. Chem. 259:3933-3943.

5. Kadonaga, J. T., K. A. Jones, and R. Tjian. 1986. Promoter-specific activation RNA polymerase II transcription by Sp1. Trends Biochem. Sci. 11:20-25.

6. Farnham, P. J.. and R. T. Schimke. 1986. In vitro transcription and delimitation of promoter elements of murine dihydrofolate reductase gene. Mol. Cell. Biol. 6:2392-2401.

7. Shimada, T., K. Inokuchi, and A. W. Nienhuis. 1986. Chromatin structure of the human dihydrofolate reductase gene promoter. J. Biol. Chem. 261:14451452 .

8. Berlin, Y. A., O. A. Kiseleva, M. N. Kolosov, M. M. Shemyakin, I. V. Vasins, and I. V. Yartseva. 1968. Aureolic acid group of anti-tumor antibiotics. Nature (Lond.). 218:193-194.

9. Van Dyke, M. W., and P. B. Dervan. 1983. Chromomycin, mithramycin, and olivomycin binding sites on heterogeneous deoxyribonucleic acid. Footprinting with (methidiumpropyl-EDTA) iron (II). Biochemistry. 22:2373-2377.

10. Miller, D. M., D. A. Polansky, S. D. Thomas, R. Ray, V. W. Campbell, J. Sanchez, and C. A. Koller. 1987. Mithramycin selectively inhibits transcription of G-C containing DNA. Am. J. Med. Sci. 30:388-394.

11. Ray, R., S. Thomas, and D. M. Miller. 1990. Mithramycin selectively inhibits the transcriptional activity of a transfected human c-myc gene. Am. J. Med. Sci. 299:203-208.

12. Koller, C. A., and D. M. Miller. 1986. Preliminary observations on the therapy of the myeloid blast phase of chronic granulocytic leukemia with plicamycin and hydroxyurea. N. Engl. J. Med. 315:1433-1438.

13. Koller, C. A., V. W. Campbell, D. A. Polansky, A. Mulhern, and D. M. Miller. 1985. In vivo differentiation of blast-phase chronic leukemia. J. Clin. Invest. 76:365-369.

14. Snyder, R. C., R. Ray, S. Blume, and D. M. Miller. 1991. Mithramycin blocks transcriptional initiation of the c-myc $\mathrm{P} 1$ and $\mathrm{P} 2$ promoters. Biochemistry. 30:4290-4297.

15. Ray, R., R. C. Snyder, S. D. Thomas, C. A. Koller, and D. M. Miller. 1989. Mithramycin blocks protein binding and function of the SV40 early promoter. $J$. Clin. Invest. 83:2003-2007.

16. Goldsmith, M. E., C. A. Beckman, and K. H. Cowan. 1986. 5' nucleotide sequences influence serum-modulated expression of a human dihydrofolate reductase minigene. Mol. Cell. Biol. 6:878-886.

17. Sive, H. L., N. Heintz, and R. G. Roeder. 1986. Multiple sequence elements are required for maximal in vitro transcription of a human histone $\mathrm{H} 2 \mathrm{~b}$ gene. Mol. Cell. Biol. 6:3329-3340.

18. Kadonaga, J. T., K. R. Carner, F. R. Masiarz, and R. Thian. 1987. Isolation of cDNA encoding transcription factor $\mathrm{Spl}$ and functional analysis of the DNA binding domain. Cell. 51:1079-1090.

19. Manley, J. L., A. Fire, A. Cano, P. A. Sharp, and M. L. Gefter. 1980. DNA-dependent transcription of adenovirus genes in a soluble whole-cell extract. Proc. Natl. Acad. Sci. USA. 77:3855-3859.

20. Cowan, K. H., M. E. Goldsmith, R. M. Levine, S. C. Aitken, E. Douglas, N. Clendeninn, A. W. Nienhuis, and M. E. Lippman. 1982. Dihydrofolate reductase gene amplification and possible rearrangement in estrogen-responsive methotrexate-resistant human breast cancer cells. J. Biol. Chem. 257:15079-15086.

21. Kadonaga, J. T., A. J. Courey, J. Ladika, and R. Tjian. 1988. Distinct regions of Spl modulate DNA binding and transcriptional activation. Science (Wash. DC). 242:1566-1570.

22. Hendrickson, S. L., J. R. Wu, and L. F. Johnson. 1980. Cell cycle regulation of dihydrofolate reductase mRNA metabolism in mouse fibroblasts. Proc. Natl. Acad. Sci. USA. 77:5140-5144.

23. Gidoni, D., W. S. Dynan, and R. Tjian. 1984. Multiple specific contacts between a mammalian transcription factor and its cognate promoters. Nature (Lond.). 312:409-413.

24. Cowan, K. H., M. E. Goldsmith, M. D. Ricciardone, R. Levine, E. Rubalcaba, and J. Jolivet. 1986. Regulation of dihydrofolate reductase in human breast cancer cells and in mutant hamster cells transfected with a human dihydrofolate reductase minigene. Mol. Pharmacol. 30:69-76.

25. Mariani, B. D., and R. T. Schimke. 1984. Gene amplification in a single cell cycle in Chinese hamster ovary cells. J. Biol. Chem. 259:1901-1910.

26. Corin, R. E., T. Turner, and P. Szabo. 1986. Murine erythroleukemia cell variants: isolation of cells that have amplified the dihydrofolate reductase gene and retained the ability to be induced to differentiate. Biochemistry. 25:37683773.

27. Dyan, W. S., and R. Tjian. 1983. The promoter-specific transcription factor Spl binds to upstream sequences in the SV40 early promoter. Cell. 35:7987.

28. Ishii, S., J. T. Kadonaga, R. Tjian, J. N. Brady, G. T. Merlino, and I. Pastan. 1986. Binding of the SP1 transcription factor by the human Harvey ras 1 proto-oncogene promoter. Science (Wash. DC). 232:1410-1413.

29. Jones, K. A., K. R. Yamamoto, and R. Tjian. 1985. Two distinct transcription factors bind to the HSV thymidine kinase promoter in vitro. Cell. 42:559-572.

30. Jones, K. A., J. T. Kadonaga, P. A. Luciw, and R. Tjian. 1986. Activation of the AIDS retrovirus promoter by the cellular transcription factor, Sp1. Science (Wash. DC.) 232:755-759.

31. Lee, W., A. Haslinger, M. Karin, and R. Tjian. 1987. Activation of transcription by two factors that bind promoter and enhancer sequences of the human metallothionein gene and SV40. Nature (Lond.). 325:368-372.

32. Azizkham, J. C., J. P. Vaughn, R. J. Christy, and J. L. Hamlin. 1986. Nucleotide sequence and nuclease hypersensitivity of the Chinese hamster dihydrofolate reductase gene promoter region. Biochemistry. 25:6228-6236.

33. Dynan, W. S., S. Sazar, R. Tjian, and R. T. Schimke. 1986. Transcription factor Spl recognizes a DNA sequence in the mouse dihydrofolate reductase promoter. Nature (Lond.). 319:246-248.

34. Mitchell, P. J., A. M. Carothers, J. H. Han, J. D. Harding, E. Kas, L. Venolia, and L. A. Chasin. 1986. Multiple transcription start sites, DNase I-hypersensitive sites, and an opposite-strand Exon in the 5 ' region of the CHO DHFR Gene. Mol. Cell. Biol. 6:425-440.

35. Dawson, P. A., S. L. Hofman, D. R. van der Westhuyzen, T. C. Sudhof, M. S. Brown, and J. L. Goldstein. 1988. Sterol-dependent repression of low density lipoprotein receptor promoter mediated by 16-base pair sequence adjacent to binding site for transcription factor Sp1. J. Biol. Chem. 263:3372-3379.

36. McKnight, S. R., and Tjian. 1986. Transcriptional selectivity of viral genes in mammalian cells. Cell. 46:795-805.

37. Bouchard, J., K. F. Bostow, M. C. Starnes, R. Prabhu, and Y. Chen. 1985. 
Characterization of dihydrofolate reductase-related DNA and RNA from human KB cell subclones containing different amounts of enzyme. Cancer Res. 45:1717-1722.

38. Frei, E, III, A. Rosowsky, J. E. Wright, C. A. Cucchi, J. A. Lippke, T. J. Ervin, J. Jolivet, and W. A. Haseltine. 1984. Development of methotrexate resistance in a human squamous cell carcinoma of the head and neck in culture. Proc. Natl. Acad. Sci. USA. 81:2873-2877.

39. Srimatkandada, S., W. D. Medina, A. R. Cashmore, W. Whyte, D. Engel, B. A. Moroson, C. T. Franco, S. K. Dube, and J. R. Bertino. 1983. Amplification and organization of dihydrofolate reductase genes in a human leukemic cell line, K-562, resistant to methotrexate. Biochemistry. 22:5774-5781.

40. Alt, F. W., R. E. Kellems, J. R. Bertino, and R. T. Schimke. 1978. Selective multiplication of dihydrofolate reductase genes in methotrexate-resistant variants of cultured murine cells. J. Biol. Chem. 253:1357-1370.

41. Bostock, C. J., E. M. Clark, N. G. L. Harding, P. M. Mounts, C. TylerSmith, V. van Heyningen, and P. M. B. Walker. 1979. The development of resistance to methotrexate in a mouse melanoma cell line. Chromosoma (Berl.). 74:153-177.

42. Kleinberger, T., S. Etkin, and S. Lavi. 1986. Carcinogen-mediated methotrexate resistance and dihydrofolate reductase amplification in Chinese hamster cells. Mol. Cell. Biol. 6:1958-1964.

43. Looney, J. E., and J. L. Hamlin. 1987. Isolation of the amplified dihydrofolate reductase domain from methotrexate-resistant Chinese hamster ovary cells. Mol. Cell Biol. 7:569-577.
44. Carman, M. D., J. H. Schornagel, R. S. Rivest, S. Srimatkandada, C. S. Portlock, T. Duffy, and J. R. Bertino. 1984. Resistance to methotrexate due to gene amplification in a patient with acute leukemia. J. Clin. Oncol. 2:16-20.

45. Curt, G. A., D. N. Carney, K. H. Cowan, J. Jolivet, B. D. Bailey, J. C. Drake, C. S. Kao-Shan, J. D. Minna, and B. A. Chabner. 1983. Unstable methotrexate resistance in human small-cell carcinoma associated with double minute chromosomes. $N$. Engl. J. Med. 308:199-202.

46. Horns, R. C., Jr., W. J. Dower, and R. T. Schimke. 1984. Gene amplification in a leukemic patient treated with methotrexate. J. Clin. Oncol. 2:2-7.

47. Gupta, R. S. 1982. Species specific differences in the toxicity of mithramycin, chromomycin $\mathbf{A}_{3}$, and olivomyin towards cultured mammalian cells. J. Cell. Physiol. 113:11-16.

48. Bleyer, W. A. 1977. Methotrexate: clinical pharmacology, current status and therapeutic guidelines. Cancer Treat. Rev. 4:87-101.

49. Tsurusawa, M., M. Niwa, N. Katano, and T. Fujimoto. 1988. Flow cytometric analysis by bromodeoxyuridine/DNA assay of cell cycle perturbation of methotrexate-treated mouse L1210 leukemia cells. Cancer Res. 48:4288-4293.

50. Ayusawa, D., K. Shimizu, H. Koyama, K. Takeishi, and T. Seno. 1983. Accumulation of DNA strand breaks during thymineless death in thymidylate synthase-negative mutants of mouse FM3A cells. J. Biol. Chem. 258:1244812454.

51. Lorico, A., G. Toffoli, M. Boiocchi, E. Erba, M. Broggini, G. Rappa, and M. D'Incalci. 1988. Accumulation of DNA strand breaks in cells exposed to methotrexate or $\mathrm{N}^{10}$-propargyl-5,8-dideazafolic acid. Cancer Res. 48:2036-2041. 